\title{
PHYTOCHEMICAL SCREENING AND ANTIMICROBIAL ACTIVITY OF ASPARAGUS RACEMOSUS WILLD. AND ASPARAGUS CURILLUS BUCH.-HAM. EX ROXB.
}

\section{ROSE SHRESTHA $^{1} \bowtie$, ASTHA SHAKYA ${ }^{2}$ AND KRISHNA KUMAR SHRESTHA ${ }^{3}$}

\author{
${ }^{1}$ Department of Plant Resources, Thapathali, Kathmandu, Nepal \\ ${ }^{2}$ Kathmandu University, Dhulikhel, Kavre \\ ${ }^{3}$ Central Department of Botany, Tribhuvan University, Kirtipur, Kathmandu, Nepal \\ roseshrestha664@yahoo.com
}

\begin{abstract}
Asparagus racemosus Willd. is an important medicinal plant of tropical and subtropical regions of Nepal and India. Its medicinal usage has been reported in the Indian and British Pharmacopoeias and in traditional systems of medicine such as Ayurveda, Unani, and Siddha. Asparagus curillus Buch-Ham.ex Roxb. is also one of the species found in higher altitude of Nepal. Its roots are used as substitute for $A$. racemosus. Phytochemical investigation was done for these two species of Nepalese Asparagus as per Methodology for Analysis of Vegetable Drugs by I. Ciulei.1982. Phytochemical screening revealed the presence of coumarin, flavonoid, catecholic tannin, reducing compound in alcoholic extract of $A$. racemosus while its aqueous extract revealed polyuronoid, reducing compound, polyoses, saponin, gallic tannin, catecholic tannin, etc. Similarly, alcoholic extract of $A$. curillus revealed catecholic tannin, reducing compound and aqueous extract revealed polyuronoid polyoses, saponin, gallic tannin as main phytochemical compounds. Comparative antimicrobial activity of ethanolic extract of these two species has been evaluated using Kirby-Bauer Agar well diffusion method. The extracts were screened for their antimicrobial activity on nine different strains of human pathogenic microorganisms such as Escherichia coli, Salmonella typhi, Bacillus subtilis, Pseudomonas aeruginosa, Staphylococcus aureus, Klebsiella pneumoniae, Enterococcus faecalies, Saccharomyces cerevisiae and Candida albicans. Among them $A$. racemosus has shown selected antimicrobial effects against $B$. subtilis, E. coli, E. faecalis, S. cerevisiae and C. albicans with zone of inhibition of $25 \mathrm{~mm}$ in an average. While A. curillus showed effects on S. cerevisiae and C. albicans only with zone of inhibition about $12 \mathrm{~mm}$.
\end{abstract}

Keywords: medicinal plant, traditional medicine, alcoholic extract, phytochemical compounds, pathogenic microorganisms

\section{INTRODUCTION}

Plants are major source of potent drugs for traditional medicine since ancient period. Secondary metabolites present in these plants are known to exhibit numerous biological activities like antibacterial, anticancer, antifungal and antioxidant activities that promote positive health effects for humans and animals. Some secondary metabolites such as plant pigments, alkaloids and isoprenoids are responsible for color, flavor, and smell in plants and have been source for drugs, 
fine chemicals, insecticides, dyes, flavors, and fragrances for human use. Similarly, steroidal glycoside in Parmelia seems to be responsible for its strong antibacterial activity (Karn, 2003).

Asparagus racemosus Willd. (Kurilo, Satavari) is an important medicinal plant of tropical and subtropical regions of Nepal and India mostly. Its medicinal usage has been reported in the Indian and British pharmacopoeias and in traditional systems of medicine such as Ayurveda, Unani, and Siddha. It is one of the top ten most traded high value medicinal plant species of Nepal having therapeutical as well as nutraceutical importance (Tiwari, 2002; Acharya, 2005). Steroidal saponin, Isoflavenoids and polysachharides are some of the major components found in this plant which are responsible for its antidiarrheal, antidysenteric, wound healing, antioxidant properties (Nagar et al., 2015). Devkota \& Dutta (2001) also studied and found antibacterial activity of Asparagus recemosus, against six bacteria (Escherichai coli, Shigella dysenteriae, Staphylococcus aureus, Pseudomonas aeruginosa, Salmonella typhi, and Vibrio cholerae). But no research so far has been carried out on Nepalese Asparagus species.

Of the 300 species of Asparagus found worldwide, Nepal harbors 7 species so far viz.Asparagus lycopodineas, Asparagus adscendens, Asparagus curillus, Asparagus filicinus (var. brevipes \& var. filicinus,), Asparagus penicillatus $\mathrm{H}$. Hara (endemic species from Dolpa), Asparagus racemosus (var. racemosus, \& var. subacerosus), and Asparagus tibeticus (new record from Mustang, in the wild. Asparagus curillus is also one of the species of Nepal found in higher altitude. It is also reported to have similar medicinal value and used as substitutes for wild asparagus (Asparagus racemosus). If its therapeutic value is proved to be equally effective it can contribute as alternative source for $A$. racemosus. The main objective of this study is to assess and compare phytochemical characteristics and antimicrobial properties of these two Asparagus species from different altitudes and habitat types and to know their potentialities of medicinal values.

\section{MATERIALS AND METHOD}

\section{Study species}

Asparagus racemosus Willd.: It is slightly scrambling sub shrubs with a short rhizomatous rootstock having cluster of fusiform tuberous roots ca. 6-14 cm long. Stem 1-2.5m long with woody base, ca. $4-5 \mathrm{~cm}$ thick and densely branched. Leaves are reduced to scales or spines. Instead cladodes are found in fascicle of 3-11, v-shaped in outline, 6-30x0.5-1 mm, straight or curved, with acuminate tip. Spines are usually curved, $1.5 \mathrm{~cm}$ long in main branch and smaller in upper branch lets. Flowers are white and produced in raceme or panicles. Fruits are berry; globose or lobed, 1-3 seeded; red when ripe. It is found around $100-2100 \mathrm{~m}$ altitude in forest floor of Nepal, E Himalaya, S E Asia, Australia, and Africa.

Asparagus curillus Buch-Ham.ex Roxb.: It is a sub-scandent shrub 1.5-3.5 1-3 m tall. Roots are long and slender, tuberous, whitish brown up to $(8-) 30-80 \mathrm{~cm}$ long. Stem is light yellow in colour, armed with spine, smooth at base and ribbed distally. Spines are straight or curved, 0.5$2.5 \mathrm{~cm}$. Branches are many ribbed and spiny with branch lets spreading and angled. Cladodes are in fascicles of 3-8(-12) number, not equal in same fascicles, and are 3--6 (--8) $\times 0.5--0.8$ $\mathrm{mm}$ long, linear flattened or sub triquetrous, straight or curved with acute tip. Inflorescence are simple or branched racemes usually with cladodes at top, 1-3 nate, axillary. Racemes are 1-8 $\mathrm{cm}$ long with 10-12 flowers. Pedicel are 3-6 mm long, jointed at middle. Bracts are lanceolate, 
1.2--1.7 mm long. Flowers are white, bisexual, $2--3 \mathrm{~mm}$ in diam. Tepals are ca. $3 \times 1 \mathrm{~mm}$, cuneiform, spreading with obtuse tip, entire, companulate. Stamens are shorter than tepals, ca. $2 \mathrm{~mm}$. Anthers are oblong, Gynoecium are clavate with style ca $2.2 \mathrm{~mm}$, stigma 3 recurved lobes. Fruit is berry, 3-4 mm long, 3 lobed and red when ripe. Seeds are $2 \mathrm{~mm}$ in length and turbinate. It is distributed in west Himalaya, Nepal along the altitudinal range of $1000-2850 \mathrm{~m}$.

\section{Plant material preparation}

The root tubers of Asparagus racemosus were collected from Kitne VDC Daman and Manahari VDC Hetauda of Makawanpur district, while that of $A$. curillus were from Dhunche VDC of Rasuwa. The voucher specimen was identified from KATH herbarium Godawari. The collected plant materials were dried in sun for few days and then at room temperature. It was then powdered and the powdered drug was stored in cool and dry place for further studies.

\section{Preparation of extracts}

Forty grams $(40 \mathrm{~g})$ of dried coarsely powdered samples was extracted with $50 \%$ ethanol by soxhlet method (Ciulei, 1982). All the extracts were completely dried keeping on water bath. Drying was done within a day. The dried extracts were then used for phytochemical analyses and antibacterial activity.

\section{Physicochemical and phytochemical tests}

The crude ethanol extract of $A$. racemosus and of $A$. curillus were subjected to preliminary phytochemical screening for the detection of major phytochemical constituents per the standard methods. Parameters such as percentage of total ash, acid-insoluble ash, water soluble ash, extractive values of water and alcohol were calculated as per the methods of Indian pharmacopoeia (Anonymous, 1996). The presence or absence of different phyto-constituents viz, triterpenoids, alkaloids, steroids, sugar, tannin, glycosides and flavonoids etc. were detected by usual prescribed methods (Culie, 1985) as follows:

\section{Etheric extract test}

Test for volatile oil: $2 \mathrm{ml}$ extractive solution were placed in a capsule and allowed to evaporate to dryness. $0.5 \mathrm{ml}$ of alcohol are added. Some drops from the concentrated alcoholic solution are placed on a filter paper. A spot formed after evaporation denotes presence of oil.

Test for alkaloids: $6 \mathrm{ml}$ extractive solution are evaporated on water bath and residue obtained is dissolved in $1.5 \mathrm{ml}$ of $2 \mathrm{~N} \mathrm{HCL}$. $0.5 \mathrm{ml}$ of this sol is reacted with 2-3 drops of Mayer's reagent (Mayer's test). Yellowish white precipitation indicates presence of alkaloids as bases.

Test for fatty acids and coumarins: $10-15 \mathrm{ml}$ extractive solution are extracted 3 times each with $1.5 \mathrm{ml}$ of $10 \% \mathrm{KOH}$ in a separating funnel on gently shaking. One aqueous alkaline solution re-acidulated with conc. HCL then extracted 3 times each with $5 \mathrm{ml}$ of ether in extraction funnel. 2 drops of this etheric solution are placed on filter paper. If the spot persists after evaporation it indicates presence of fatty acids. $2 \mathrm{ml}$ of etheric solution were concentrated till the residue is obtained. It is then dissolved in hot water. After cooling the sol was divided in two tubes: one tube will serve as standard. Aqueous solution of second tube was made alkaline with $0.5 \mathrm{ml}$ of $10 \% \mathrm{NH} 4 \mathrm{OH}$ and observed under UV light. The occurrence of intense fluorescence under 
UV light indicates presence of coumarins and derivatives.

Test for flavenoids: $2 \mathrm{ml}$ of etheric solution were concentrated till residue was obtained. The residue was dissolved in 1-2 $\mathrm{ml}$ of $50 \%$ methanol by warming up with metal magnesium and 2-3 drops of conc. HCL was added. A red or orange color indicates the presence of flavenoids. $2 \mathrm{ml}$ of etheric solution is concentrated till it gives a residue which is dissolved in $0.5 \mathrm{ml}$ of acetic anhydride and $0.5 \mathrm{ml}$ of chloroform. The solutions are transformed to a dry tube and, at its bottom added 1-2 $\mathrm{ml}$ of conc. $\mathrm{H} 2 \mathrm{SO} 4$ (Liebermann-Brofad's reagent). At contact zone of two liquid violet ring is formed, superior layer becomes green gallic denoting presence of sterols and some triterpenes respectively.

\section{Alcoholic extract test}

Test for tannin: $0.5 \mathrm{ml}$ of alcoholic extractive solution was diluted with $1 \mathrm{ml}$ of water and 2-3 drops of diluted $\mathrm{FeCl} 3$ (light yellow) are added. The occurrence of a blue-blackish precipitate shows presence of gallic tannins and a green-blackish color indicates catchcolic tannins.

Test for reducing compounds: $0.5 \mathrm{ml}$ of alcoholic extractive solution are diluted with $1 \mathrm{ml}$ of water and $0.5 \mathrm{ml}$ of Fehling (I and II) solution and warmed up. A red brick precipitate denotes the presence of reducing compounds.

Test for coumarin derivatives: $4 \mathrm{ml}$ of etheric solution was concentrated till a residue remains. A residue obtained thus was dissolved in $1-2 \mathrm{ml}$ water by heating if needed. The aqueous solution is divided in two equal volumes, in two tubes. To one of the tube $0.5 \mathrm{ml}$ of $10 \% \mathrm{NH} 4 \mathrm{OH}$ are added, the other tube serving as standard. The presence of blue, violet fluorescence under UV light, deeper for alkaline solution indicates the presence of coumarin.

Test for glycosides: To $10-15 \mathrm{ml}$ of alcoholic extractive solution, an equal volume of $10 \% \mathrm{HCL}$ added by refluxing and heated for 30 minutes. During hydrolysis, the solution becomes turbid due to precipitation of aglycones resulted by the division of the glycosides. After cooling the solution is extracted 3 times each in a separating funnel, with 6-8 $\mathrm{ml}$ of ether. The etheric extractive solutions are placed together $(16-20 \mathrm{ml})$ and dehydrated with dry NA2SO4 thus resulting and etheric and aqueous solution. The etheric solution will serve to identify anthracenoside of coumarin, the flavonoids, glycosides, sterols and triterpenes by means of specific test to aglycones.

Test of anthracenoside: $4 \mathrm{ml}$ of etheric solution are concentrated till $2 \mathrm{ml}$ remains, then 1-2 $\mathrm{ml}$ of $25 \% \mathrm{NH} 4 \mathrm{OH}$ were added by shaking. A cherish red colour of the alkaline solution indicates the presence of emodine (aglycones of anthracenoside) in an oxidized form (Brontrager's reation)

Test of flavonic glycosides: $4 \mathrm{ml}$ of an etheric solution are concentrated to residue which is then dissolved in 1-2 $\mathrm{ml}$ of 50\% methanol y heating. Metal magnesium and 5-6 drops of conc. HCL (Shibata's reaction) were added. The red solution indicates presence flavonoid, orange indicates flavones and violet for flavonones.

Test for stero/s: Liebermann-Burchard test: $4 \mathrm{ml}$ of etheric solution are concentrated till a residue is obtained. It is dissolved in $0.5 \mathrm{ml}$ of acetic anhydride and $0.5 \mathrm{ml}$ of chloroform. By means of a pipette, 1-2 $\mathrm{ml}$ of conc. $\mathrm{H} 2 \mathrm{SO} 4$ are placed at the bottom. At the separating level of the two liquids, a brown reddish or brown violet ring is formed, the superior layer being blue green (for sterol) or violet (often for triterpenes) 
Test for saponin: Small amount of extracts was shaken with little quantity of water vigorously. The foam generationthat persists for 10 minutes indicates the presence of saponin.

Test for alkaloids: $4.5 \mathrm{ml}$ alcoholic extract solution are pipetted in a capsule and concentrated on the boiling water. To the residue, $1-2 \mathrm{ml}$ of $2 \% \mathrm{HCl}$ are added.

\section{Antimicrobial activity}

Comparative antimicrobial activity of ethanolic extract of these two species has been evaluated using Kirby-Beaur Agar well diffusion method. The extracts were screened for their antimicrobial activity on nine different strains of human pathogenic microorganisms such as Escherichia coli, Salmonella typhi, Bacillus subtilis, Pseudomonas auruginosa, Staphylococcus aureus, Klebsiella pneumoniae, Enterococcus faecalies, Sachharomyces ceravisae and Candida albicans. The latter two S. ceravisae and $C$. albicans are fungal pathogens. The bacterial and fungal cultures were provided by Microbiology section of Department of Plant Resources. All the bacterial organism was prepared in $10 \mathrm{ml}$ of Muller Hinton agar (MHA) broth culture and incubated at $370 \mathrm{C}$ for $24 \mathrm{~h}$. Then it was inoculated in MHA agar plate by cotton swab ensuring uniform carpeting of organism to cover the media and dried in incubation for $1 \mathrm{~h}$. After that wells of $6 \mathrm{~mm}$ diameter were punched in the medium using sterile borer and $50 \mu \mathrm{l}$ of the extracts $(100 \mathrm{mg} / \mathrm{ml}$ concentration) were poured to the respective wells and $50 \mu \mathrm{l}$ of the solvent $(50 \%$ ethanol) was poured to one well as control. All the plates were kept as it is for few minutes for effective diffusion of the extracts. Later they were incubated at $370 \mathrm{C}$ for $24 \mathrm{~h}$. Similarly, for fungal microorganisms same process was followed using SDA media and incubation at $270 \mathrm{C}$.

Antibacterial and anti-fungal activity was observed after $24 \mathrm{hrs}$. The diameter of the inhibition zones was measured. The average area of zone of inhibition was calculated and compared with that of the standards. Similarly, Minimum Bactricidal Concentration (MBC) and Minimum Fungicidal Concentration (MFC) of effective plant extracts were evaluated by two fold serial dilution method (CLSI, 2006).

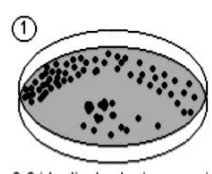

2-3 identical colonies are picked from the plate and transferred to the broth

zone of inhibition

(5)

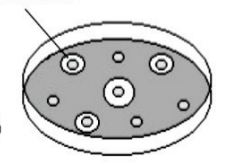

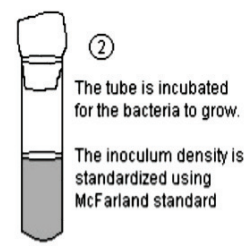

50 ul extract $(1 \mathrm{mg} / 1 \mathrm{ml})$ is pipetted into well labelled wells

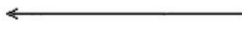

Incubate at $37^{\circ} \mathrm{C}$ for $24 \mathrm{hrs}$

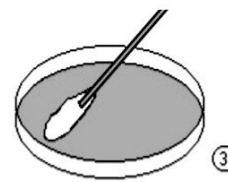

A cotton swab dipped in the inoculum suspension is swabbed over the entire surface of agar to give a lawn culture.

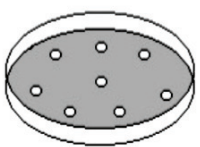

$6 \mathrm{~mm}$ diameter wells are made

fig: Antimicrobial screening by Agar Well Diffusion Method 


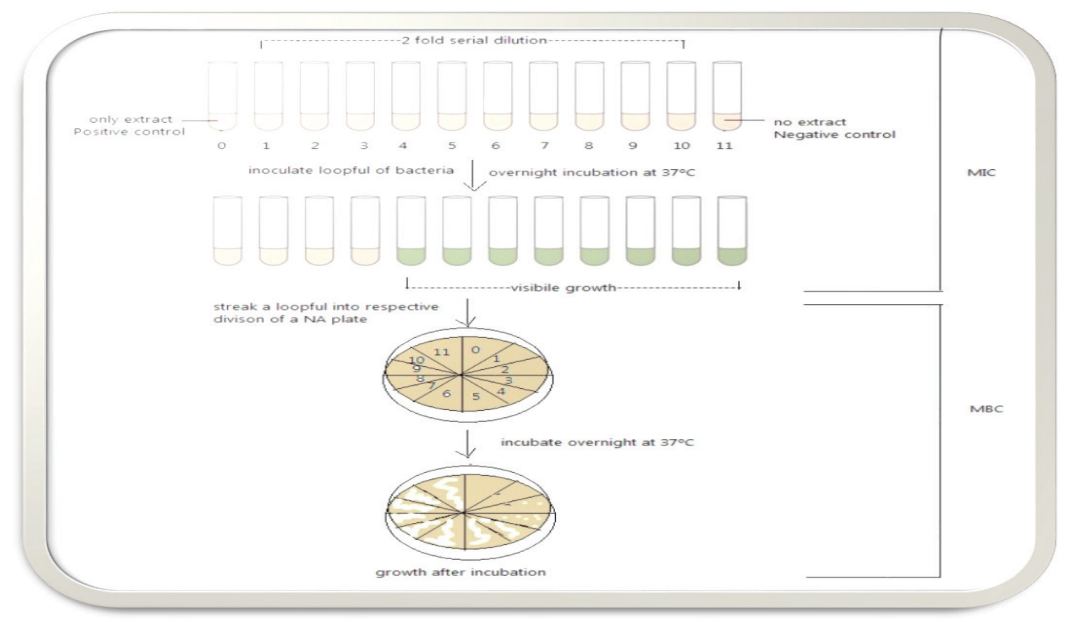

FIG. 2. MBC/MFC evaluation by two-fold serial dilution method (CLSI, 2006).

\section{RESULTS AND DISCUSSION}

\section{Phytochemical screening of study species}

Phytochemical screening revealed the presence of coumarin, flavonoid, catecholic tannin, reducing compound in alcoholic extract of $A$. racemosus while its aqueous extract revealed polyuronoid, reducing compound, polyoses, saponin, gallic tannin, catecholic tannin, etc. Similarly alcoholic extract of $A$. curillus revealed catecholic tannin, reducing compound and aqueous extract revealed polyuronoid polyoses, saponin, gallic tannin as main phytochemical compounds (table 1). Similar results were revealed showing the presence of alkaloids, glycosides, phenolic compounds, tannins, saponins, steroids, flavonoids and carbohydrates (Sharma \& Sharma, 2013; Shevale et al., 2015). Asparagus racemosus is one of the important medicinal plant used worldwide showing the properties to use for prevention and treatment of gastric ulcers, dyspepsia and as a galactotgogue. It is also used successfully for nervous disorders, inflammation, liver diseases and certain infectious diseases (Patel \& Patel, 2013; Shevale et al., 2016). 
TABLE 1. Phytochemical constituents of study species.

\begin{tabular}{|l|l|l|}
\hline Extract solvent & Asparagus racemosus & Asparagus curillus \\
\hline Petroleum ether & Volatile oil & Steroids, fatty acids \\
\hline Ethyl alcohol extract & $\begin{array}{l}\text { Coumarin, flavenoid, Catecholic tanin, } \\
\text { reducing compound }\end{array}$ & Catecholic tanin, reducing compound \\
\hline Aqueous extract & $\begin{array}{l}\text { Polyuronoid, reducing compound, } \\
\text { polyoses, Saponin, Gallic tanin, } \\
\text { catecholic tannin }\end{array}$ & $\begin{array}{l}\text { Polyuronoid, reducing compound, } \\
\text { polyoses, saponin, gallic tanin, } \\
\text { catecholic tanin }\end{array}$ \\
\hline
\end{tabular}

Physico-chemical parameters and extractive values were in the range of standard value coated by the Indian pharmacopeia (table 2).

TABLE 2. Physicochemical characteristics.

\begin{tabular}{|l|l|l|l|l|l|}
\hline SN & Name of species & $\begin{array}{l}\text { Total ash } \\
(\%) \\
\text { (wet basis) }\end{array}$ & Moisture (\%) & $\begin{array}{l}\text { Water soluble } \\
\text { Ash (\%) }\end{array}$ & $\begin{array}{l}\text { Acid insoluble } \\
\text { ash (\%) }\end{array}$ \\
\hline 1 & $\begin{array}{l}\text { Asparagus racemosus } \\
\text { (Makwanpur) }\end{array}$ & 5.88 & 6.01 & 2.34 & 0.96 \\
\hline 2 & $\begin{array}{l}\text { Asparagus curillus } \\
\text { (Rasuwa) }\end{array}$ & 3.52 & 10.17 & 1.24 & 0.66 \\
\hline 3 & $\begin{array}{l}\text { Standard value } \\
\text { (Gupta et al., 2003) }\end{array}$ & $<6$ & 11 & NA & $<1$ \\
\hline
\end{tabular}

\section{Antimicrobial susceptibility assay}

The extracts were screened for their antimicrobial activity on nine different strains of human pathogenic microorganisms such as E. coli, S. typhi, B. subtilis, P. aeruginosa, S. aureus, $K$. pneumoniae, E. faecalis, S. cerevisiae and C. albicans. Among them latter two are fungal pathogen and rest other are bacterial pathogen.

A. racemosus showed selected antimicrobial effects against B. subtilis, E. coli, E. faecalis, $P$. aeruginosa, S. cerevisiae and $C$. albicans with zone of inhibition of $25 \mathrm{~mm}$ in an average. While $A$. curillus showed effects on $S$. cerevisiae and $C$. albicans only with zone of inhibition about 12 (fig. 3, plate $1 \& 2$ ). MFC values of $A$. curillus for $C$. albicans was $12.5 \mathrm{mg} / \mathrm{m}$ and $S$. cerevisiae was $6.25 \mathrm{mg} / \mathrm{ml}$ while MFC of $A$. racemosus against C.albicans was $0.78 \mathrm{mg} / \mathrm{ml}$ and S. cerevisiae was $1.56 \mathrm{mg} / \mathrm{ml}$. To compare with Gentamycin it was said to be resistant if it is less than $12 \mathrm{~mm}$ and susceptible if it is more than $15 \mathrm{~mm}$ (Hudzicki, 2009). 

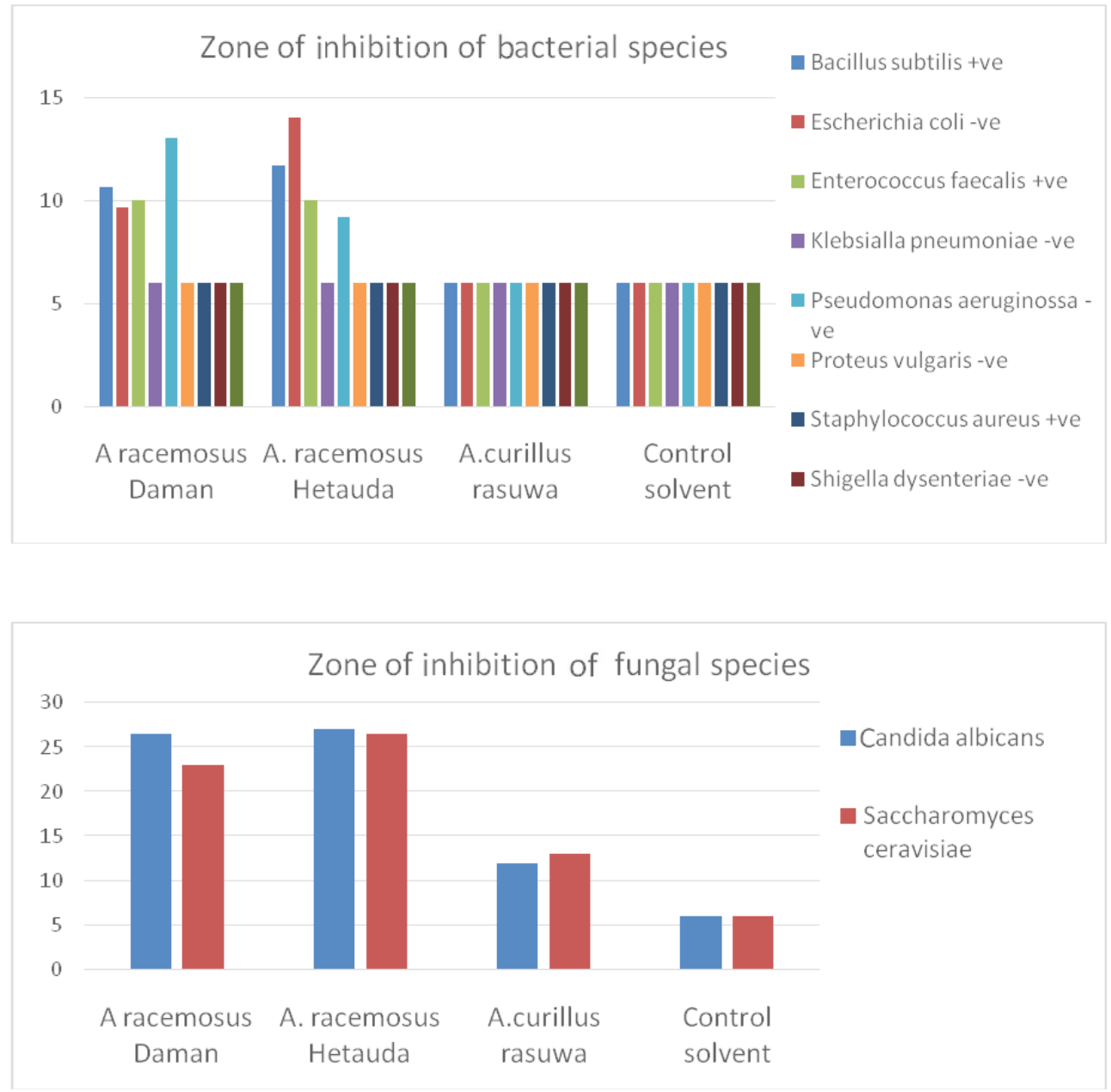

FIG. 3. Antimicrobial activities of root extracts of Asparagus racemosus and Asparagus curillus. 


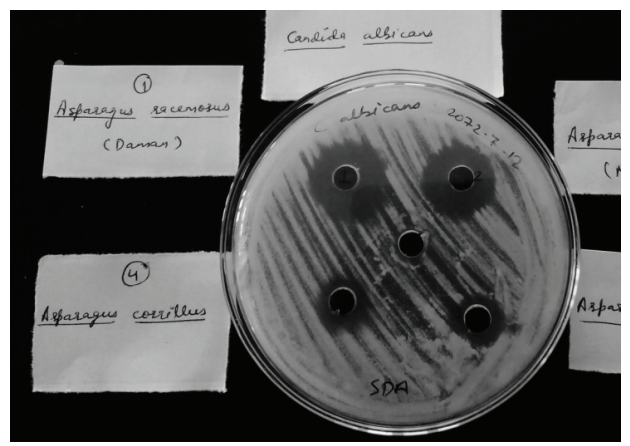

(a)

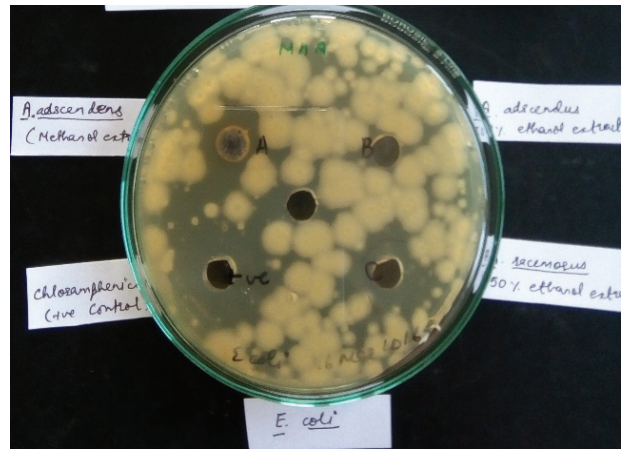

(c)

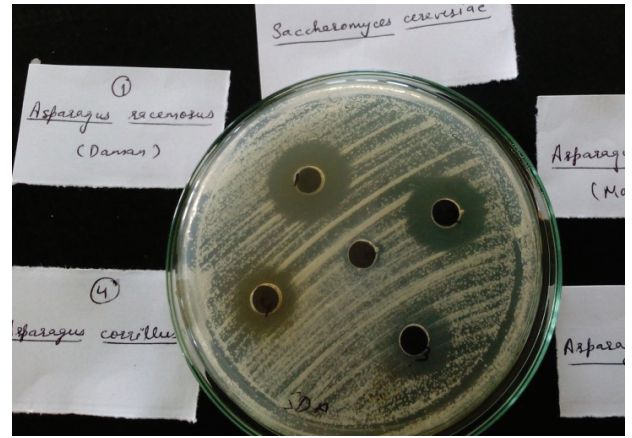

(b)

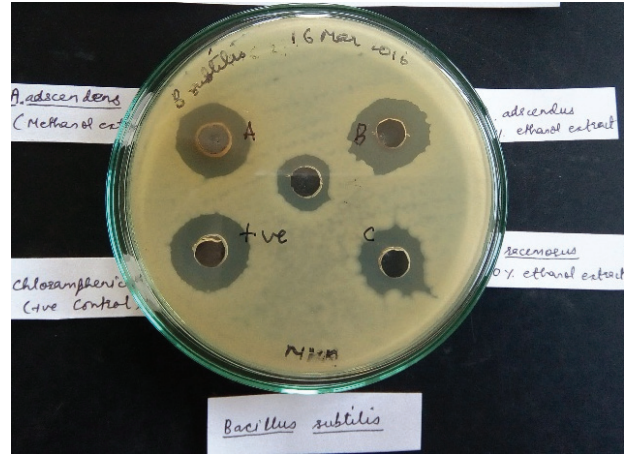

(d)

PLATE 1. Zone of inhibition by plant extract on Candida albicans (a), Saccharomyces cerevisiae (b), Escherichia coli (c) and Bacillus subtilis (d).

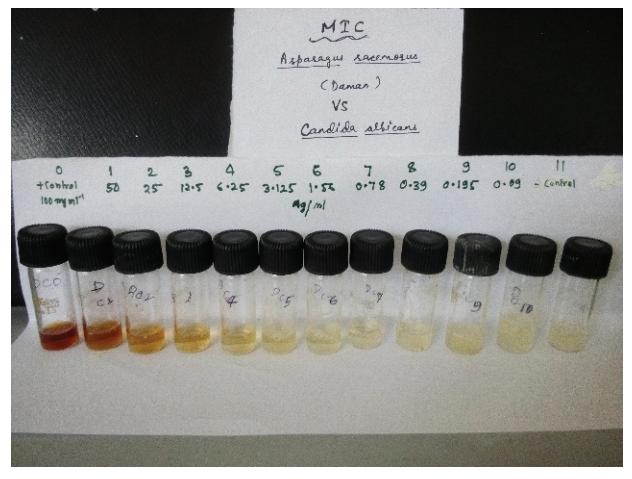

(a)

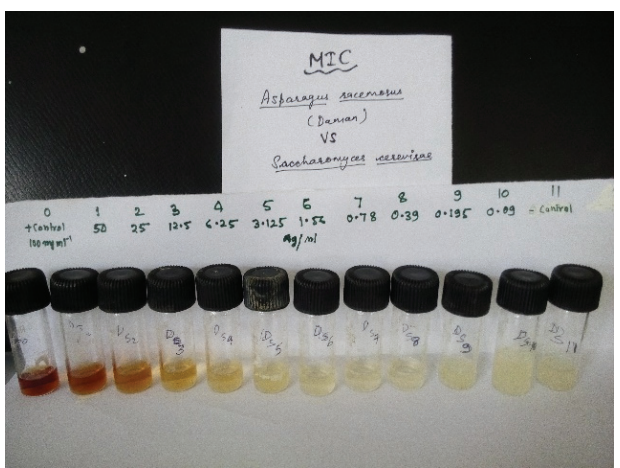

(b)

PLATE 2. Minimum inhibition Concentration (MIC) evaluation test for Asparagus racemosus vs. Candida albicans (a) and Saccharomyces cerevisiae (b). 


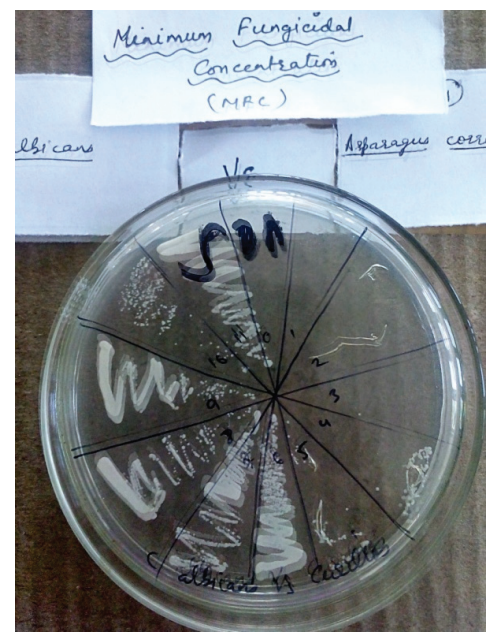

MFC values of Asparagus curillus vs Candida albicans.

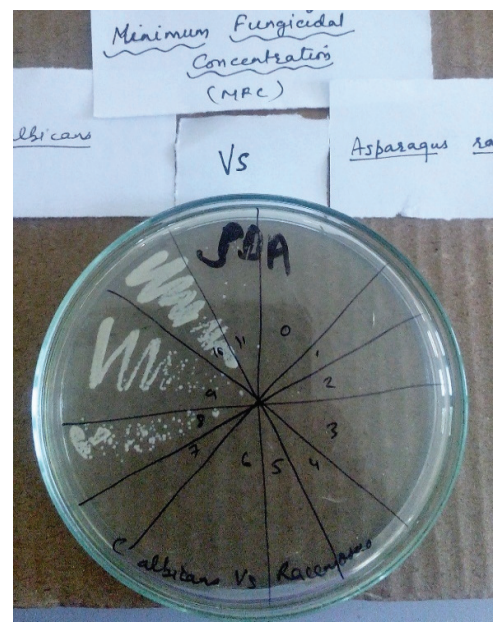

MFC values of Asparagus racemosus vs Candida albican.

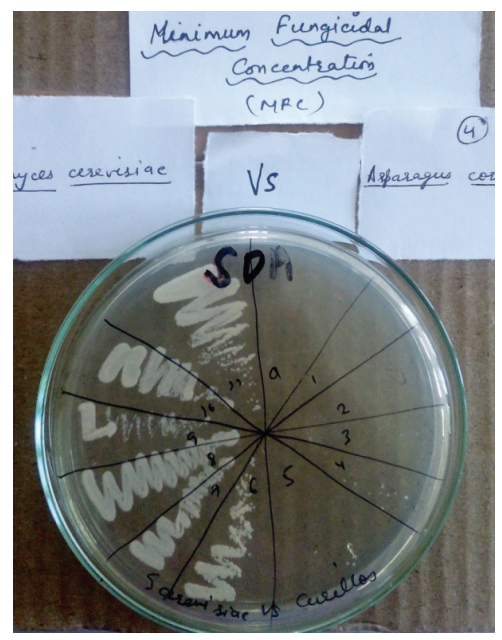

MFC values of Asparagus curillus vs Saccharomysis cerevisiae.

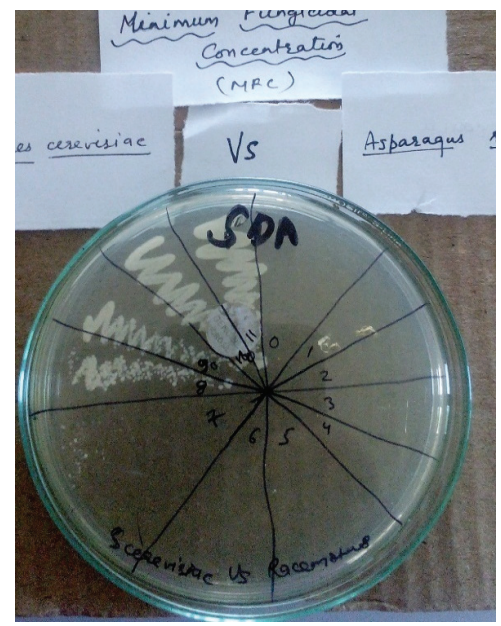

MFC values of Asparagus racemosus vs Saccharomyces cerevisiae.

PLATE 3. MBC/MFC tests for plant extracts on fungal and bacterial species. 
Steroidal triterpenoid of A. racemosus showed considerable antibacterial activities against $E$. coli and $S$. aureus while no significant activity was observed against $S$. typhi. (Shah, et. al .,2014). Similarly, Devkota \& Dutta (2001) studied and found antibacterial activity of $A$. recemosus, against six bacteria (E. coli, Shigella dysenteriae, Staphylococcus aureus, P. aeruginosa, Salmonella typhi, and Vibrio cholerae). The inhibition of both Gram positive and Gram negative bacteria by the solvent extracts indicated the presence of broad spectrum antibacterial substances in the plant root. The result was significant and supported the traditional use of Asparagus racemosus in several ailments. (Sinha \& Biswas, 2011)

Phytochemical screening revealed the presence of coumarin, flavonoid, catecholic tannin, reducing compound in alcoholic extract of $A$. racemosus while its aqueous extract revealed polyuronoid, reducing compound, polyoses, saponin, gallic tannin, catecholic tannin, etc. Similarly, alcoholic extract of $A$. curillus revealed catecholic tannin, reducing compound and aqueous extract revealed polyuronoid polyoses, saponin, gallic tannin as main phytochemical compounds. Physico-chemical parameters and extractive values were in the range of standard value coated by the Indian pharmacopeia.

Antimicrobial activity was better in A. racemosus showing its activity with $B$. subtilis, $E$. coli, E. faecalis, $S$. cerevisiae and $C$. albicans than $A$. curillus which showed activity only with $S$. cerevisiae and $C$. albicans. A.curillus has though somehow similar in chemical constituent is found ineffective in bactericidal activity but is positive in antifungal activities

As the main objective of the study is to assess and compare phytochemical characteristics and antimicrobial properties of these two Asparagus species, it is concluded that $A$. curillus is lower in quality than $A$. racemosus and can be considered adulterant not substitute. This study highlighted the potential of $A$. racemosus to be further explored as a source of bioactive natural products.

\section{ACKNOWLEDGEMENTS}

We are very grateful to Mr. Rajdev Prasad Yadav, Director General, Department of Plant Resources (DPR) and Prof. Dr. P.K. Jha, Chief, Central Department of Botany, Tribhuvan University, Kirtipur for the inspirational support for this study. We would also like to extend our appreciation to National Academy of Science and Technology (NAST), Khumaltar, Kathmandu for research grant for the study. Sincere thanks goes to Ms. Sushma Upadhyaya, Deputy Director General, DPR, Ms. Jyoti Joshi Bhatta, Chief, Natural Product Research Laboratory, DPR and Section Chief \& team members, Microbiology Section, DPR, Thapathali for laboratory support. We also like to thank Mr. Ramesh basnet, Chief.

\section{REFERENCES}

ACHARYA, R P (2010) PSPL-Report on market study of seven MAPs in far and mid-western Dev. Region. A report submitted to Department of Plant Resources, Kathmandu, Nepal.

ANONYMOUS (1996) Indian pharmacopoeia. Vol II, Government of India, Ministry of Health, New Delhi, India.

CIULEI, I (1982) Practical manuals on the industrial utilization of chemical and aromatic plants: methodology for analysis of Vegetable drugs. Ministry of Chemical Industry, Bucharest (1st edition). 
CLINICAL LABORATORY STANDARDS INSTITUTE (2006) Performance standards for antimicrobial disk susceptibility tests; approved standard. CLSI document M2-A9. 26:1. Clinical Laboratory Standards Institute, Wayne, PA (9th edition).

DEVKOTA, KP; DUTTA, IC (2001) Antibacterial activities of commercially traded herbs used in traditional medicines in communities of Doti district, Nepal. A report submitted to IUCN, Kathmandu, Nepal.

HUDZICKI, J (2009) Kirby-Bauer Disk Diffusion Susceptibility Test Protocol. ASM Microbe Library. American Society for Microbiology. http://www.microbelibrary.org/component/resource/laboratory-test/3189-kirbybauer-diskdiffusion- susceptibility-test-protocol.

KARN, AK (2003) Relationship between contribution to local livelihood and antibacterial activities of selected medicinal plants: A case study from Makawanpur district, Nepal. MSc. dissertation, Tribhuvan University, Institute of Forestry, Pokhara, Nepal.

NAGAR, BP; DUTT, VG; DHIMAN, A (2015) Pharmacognostical standardisation of root tubers of Asparagus racemosus Willd. Journal of Pharmaceutical and Scientific Innovation 4(4): 222-225. http://doi. org/10.7897/2277-4572.04450.

PATEL, LS; PATEL, RS (2013) Antimicrobial activity of Asparagus Racemosus Willd. from leaf extracts - a medicinal plant. International Journal of Scientific and Research Publications 3(3): 2250-3153.

SHAH, MA; ABDULLAH, SM; KHAN, MA; NASAR, G; SABA, I (2014) Antibacterial activity of chemical constituents isolated from Asparagus racemosus Will. Bangladesh Journal of Pharmacology 9 1): 1-3. http://doi.org/10.3329/bjp.v9i1.16672.

SHEVALE, U L; MUNDRAWALE, AS; YADAV, SR; CHAVAN, JJ; JAMDADE. CB; R. P D (2016) Phytochemical and antimicrobial studies on Asparagus racemosus. World Journal of Pharmaceutical Research 4 (9): 1805-1810.

SINHA, SN; BISWAS, M (2011) Effect of extracts from Asparagus racemosus Willd. root against pathogenic bacteria. International Journal of Applied Biology and Pharmaceutical Technology 2(3): 312-314. www.ijabpt.com

WHO (1998) Macroscopic and microscopic examination: quality control methods for medicinal plant materials. WHO, Geneva. 